\title{
Article \\ Chitosan and Lemon Extract Applied during Giuncata Cheese Production to Improve the Microbiological Stability
}

\author{
Daniela Gammariello, Massimiliano Attanasio, Matteo Alessandro Del Nobile * (D) and Amalia Conte (D)
}

check for updates

Citation: Gammariello, D.; Attanasio, M.; Nobile, M.A.D.; Conte, A. Chitosan and Lemon Extract Applied during Giuncata Cheese Production to Improve the Microbiological Stability. Appl. Sci. 2021, 11, 7446. https://doi.org/10.3390/app11167446

Academic Editor: Lidia Feliu

Received: 28 June 2021

Accepted: 5 August 2021

Published: 13 August 2021

Publisher's Note: MDPI stays neutra with regard to jurisdictional claims in published maps and institutional affiliations.

Copyright: (c) 2021 by the authors. Licensee MDPI, Basel, Switzerland. This article is an open access article distributed under the terms and conditions of the Creative Commons Attribution (CC BY) license (https:// creativecommons.org/licenses/by/ $4.0 /)$
Department of Agricultural Sciences, Food and Environment, University of Foggia, Via Napoli 25, 71122 Foggia, Italy; daniela.gammariello@unifg.it (D.G.); massimiliano.attanasio@unifg.it (M.A.); amalia.conte@unifg.it (A.C.)

* Correspondence: matteo.delnobile@unifg.it; Tel.: +39-08-8158-9242

Featured Application: Two natural compounds were investigated for antimicrobial activity against specific spoilage of fresh cheese. Results from the current study could found interest in dairy sector because the two natural compounds were found effective in preserving Giuncata cheese.

\begin{abstract}
In this study, lemon extract and chitosan were used as antimicrobial agents during Giuncata cheese production in order to assess whether the natural compounds would improve the cheese's microbial quality. In particular, the viable cell concentration of the main spoilage microbial growth (Pseudomonas spp. and total coliforms) was monitored during refrigerated storage at $4{ }^{\circ} \mathrm{C}$. A central composite design (CCD) was adopted to highlight a possible synergic effect of the two selected compounds. The results showed that a decrease in the cell growth rate of the monitored spoilage microorganisms was observed for all cheese samples added with active agents, when compared with the control cheese. Despite the recorded antimicrobial activity, an antagonist effect was detected when the two compounds were combined at the highest concentrations. In fact, the best performance was obtained when the lemon and the chitosan were used individually at concentrations of 500 and 60 ppm, respectively.
\end{abstract}

Keywords: fresh cheese; Giuncata; chitosan; lemon extract; antimicrobial agent; natural compound

\section{Introduction}

Giuncata cheese is a typical fresh cheese from the Apulia region (Italy). It is made from cow's milk and it takes its name from the specific container used for the draining process of cheese, which, in the Italian language, is called "giunco". It is produced with milk heated to $80^{\circ} \mathrm{C}$ and then cooled to $32-38^{\circ} \mathrm{C}$ and coagulated over 25-30 min without adding a starter culture but with the addition of calf or lamb liquid rennet. The curd is collected and drained into the above-mentioned specific container. In fresh cheese, there is no rind and the dough is white. The texture is soft and slightly consistent. The odour of the Giuncata cheese is generally fine and delicate, while the flavour is mainly acidic, depending on the prevalent lactic acid bacteria species that are present in the milk and then in the cheese [1]. Giuncata is usually packaged under an ordinary atmosphere and stored under refrigerated conditions for a storage time that lasts only $4-5$ days.

In recent years, food science and technology interest has been driven to innovate in the field of food shelf-life extensions as a consequence of the need for food business operators to adapt to new distribution systems and the change in the eating habits of the consumers. An extended shelf-life is a differentiating attribute for businesses that is capable to meet the modern trends of dynamic lifestyles, where consumers are less and less engaged with food courses and meal preparation [2].

In particular, shelf-life extension in the dairy sector can be considered an innovation that positively leads to improvements in product quality, production efficiency and logistic management along the supply chain. From the side of technological innovation, several solutions have been studied to extend the shelf-life of dairy products in terms of food 
formulations, new processes and packaging systems [3-6]. However, the scientific literature that has investigated dairy product shelf life does not include specific information on a typical cheese, such as Giuncata. In fact, to the best of our knowledge, only one article is available on this specific dairy food and it investigated Giuncata packaging under MAP conditions [7]; therefore, there is the need to further explore the potential of different preservation strategies.

Among the various mild solutions for dairy food that involve alternatives to MAP, particular attention is focused on natural preservatives and active compounds derived from animals or plants, such as chitosan and essential oils [8-10].

Chitosan gained significant attention and was evaluated for numerous applications other than food, mainly due to its high biodegradability and antimicrobial properties [11-13]. Specifically, in the dairy sector, other researchers successfully tested its application as an active agent in mozzarella cheese [14]. Moreover, researchers also assessed combinations of chitosan with other preservation strategies that could further improve the shelf life of fresh cheese $[3,15,16]$. The biological activity of chitosan depends on its molecular weight, deacetylation degree, chitosan derivatization, degree of substitution, length and position of a substitute in glucosamine units of chitosan, solution $\mathrm{pH}$ and, of course, the target microorganisms [17,18].

The antimicrobial activity of essential oils was recognized long ago, and numerous applications to food as natural compounds were found recently [19-23]. The antimicrobial properties of plant essential oils against a wide spectrum of microbes, including bacteria, yeasts and fungi, are well known [24-26]. The ability of essential oils to differently inhibit Gram-positive or Gram-negative bacteria is of considerable importance in the food industry. It has generally been found that a greater concentration of essential oils is needed to achieve the same effect in foods compared to the same antibacterial in an in vitro assay [27]. The great availability of nutrients in foods, compared to the laboratory media, may enable bacteria to repair damaged cells [28]. In addition, both the intrinsic (fat, protein, water content, antioxidants, $\mathrm{pH}$, salt and other additives) and extrinsic properties (temperature, packaging in vacuum/gas/air, characteristics of microorganisms) of food can influence bacterial sensitivity to natural extracts from plants [29].

Due to a lack of information about chitosan or essential oils applied to Giuncata, in the present study, for the first time, these two compounds were combined during the cheese-making process according to a central composite design (CCD). Single and combined effects of these two active agents on the cheese's microbial quality were assessed. Towards this aim, the microbiological quality of Giuncata, which was properly prepared with and without the two active compounds, was assessed by monitoring the main spoilage bacteria (Pseudomonas spp. and total coliforms) during the refrigerated storage period. To quantitatively determine the effectiveness of the investigated antimicrobial compounds, the time at which the viable cell concentration of the spoilage microorganisms reached the maximum acceptability limit was calculated.

\section{Materials and Methods}

\subsection{Giuncata Cheese Production Process}

The Giuncata cheese used in this study was manufactured in the dairy plant "Posta la Via" (Foggia, Italy) according to the following procedure: the cow milk was heated to $80^{\circ} \mathrm{C}$ and then cooled to $38^{\circ} \mathrm{C}$ and liquid calf rennet was added. Curd formation was achieved after 45-60 min, and then the curd was cut, collected and drained in specific containers. Simultaneously, different batches of modified cheese were made by adding high-molecular-weight chitosan $(\mathrm{PM}=310,000-375,000 \mathrm{Da}$ and viscosity $=800-2000 \mathrm{cP})$ (Sigma-Aldrich, Milan, Italy) and lemon extract (Boyajian, Canton, MA, USA) to working milk. The lemon extract used was a mixture of hydrocarbons, oxygenated compounds and non-volatile residues, including terpenes, sesquiterpenes, aldehydes, alcohols, esters and sterols. The concentration values varied according to a two-factor, five-level central composite design (CCD). The 11 variable combinations used are listed in Table 1 . When 
the two-factor, five-level CCD was set, 9 different runs and two further repetitions of the central point (level 0, runs 10 and 11) could be found. Each run combination was repeated twice. The samples were stored at $4{ }^{\circ} \mathrm{C}$ for 8 days.

Table 1. Level, run, experimental factors and concentrations of the central composite design.

\begin{tabular}{|c|c|c|c|c|}
\hline & \multicolumn{2}{|c|}{ Level } & $\begin{array}{c}\text { Lemon Extract } \\
(\mathrm{ppm})\end{array}$ & $\begin{array}{c}\text { Chitosan } \\
\text { (ppm) }\end{array}$ \\
\hline & \multicolumn{2}{|c|}{-2} & 0 & 0 \\
\hline & \multicolumn{2}{|c|}{-1} & 250 & 30 \\
\hline & \multicolumn{2}{|c|}{0} & 500 & 60 \\
\hline & \multicolumn{2}{|c|}{+1} & 750 & 90 \\
\hline & \multicolumn{2}{|c|}{+2} & 1000 & 120 \\
\hline Sample & \multicolumn{2}{|c|}{ Experimental Factors } & $\begin{array}{c}\text { Lemon Extract } \\
(\mathrm{ppm})\end{array}$ & $\begin{array}{c}\text { Chitosan } \\
\text { (ppm) }\end{array}$ \\
\hline Run 1 & -1 & -1 & 250 & 30 \\
\hline Run 2 & -1 & +1 & 750 & 30 \\
\hline Run 3 & +1 & -1 & 250 & 90 \\
\hline Run 4 & +1 & +1 & 750 & 90 \\
\hline Run 5 & -2 & 0 & 500 & 0 \\
\hline Run 6 & +2 & 0 & 500 & 120 \\
\hline Run 7 & 0 & -2 & 0 & 60 \\
\hline Run 8 & 0 & +2 & 1000 & 60 \\
\hline Run 9 & 0 & 0 & 500 & 60 \\
\hline Run 10 & 0 & 0 & 500 & 60 \\
\hline Run 11 & 0 & 0 & 500 & 60 \\
\hline
\end{tabular}

\subsection{Microbiological Analyses}

Microbiological analyses were performed before the packaging took place and after $1,2,4,5,6,7$ and 8 days of storage. Twenty grams of cheese were diluted in $180 \mathrm{~mL}$ of Ringer's solution and homogenized in a blender (Stomacher, International PBI, Milan, Italy). The Ringer's solution composition ( $\mathrm{pH}$ at $25^{\circ} \mathrm{C}=7 \pm 0.2$ ) was: $8.5 \mathrm{Gms} / \mathrm{L}$ sodium chloride, $0.2 \mathrm{Gms} / \mathrm{L}$ potassium chloride, $0.2 \mathrm{Gms} / \mathrm{L}$ calcium chloride anhydrous and $0.01 \mathrm{Gms} / \mathrm{L}$ sodium bicarbonate. Subsequent serial dilutions were made in the Ringer's solution and plated in the following media: PCA, incubated at $30^{\circ} \mathrm{C}$ for $48 \mathrm{~h}$ for total mesophilic bacteria; MRS agar, supplemented with cycloheximide (100 mg/L) (Sigma), incubated under anaerobiosis (Anaerogen Gas Pack, Oxoid) at $37{ }^{\circ} \mathrm{C}$ for $48 \mathrm{~h}$ for lactic acid bacteria; M17 agar, incubated at $37^{\circ} \mathrm{C}$ for $48 \mathrm{~h}$ for coccus-shaped lactic acid bacteria; VRBLA incubated at $37^{\circ} \mathrm{C}$ for $24 \mathrm{~h}$ for total coliforms; Pseudomonas Agar Base, added with SR103 E selective supplement (Oxoid) and incubated at $25^{\circ} \mathrm{C}$ for $48 \mathrm{~h}$ for Pseudomonas spp. All media were from Oxoid (Milan, Italy).

The $\mathrm{pH}$ determination was performed at the same sampling time using a $\mathrm{pH}$ meter (Crison, 2001). Measures were carried out twice on two different cheese samples.

\subsection{Modeling of Experimental Data}

The specific microbiological acceptability limit (MAL) values of each monitored spoilage microbial group were obtained by fitting the Gompertz Equation (1) as reparameterized by Gammariello et al. [30] to the microbial growth data:

$$
\begin{aligned}
\log (N(t))= & \log \left(N_{\max }\right)-A \cdot \exp \left\{-\exp \left\{\left\lfloor\left(\mu_{\max } \cdot 2.71\right) \cdot \frac{\lambda-M A L}{A}\right\rfloor+1\right\}\right\} \\
& +A \cdot \exp \left\{-\exp \left\{\left\lfloor\left\lfloor\left(\mu_{\max } \cdot 2.71\right) \cdot \frac{\lambda-t}{A}\right\rfloor\right\rfloor+1\right\}\right\}
\end{aligned}
$$

where $N(t)$ is the viable cell concentration (CFU/g) at time $t, A$ is related to the difference between the decimal logarithm of the maximum bacteria growth attained at the stationary phase and the decimal logarithm of the initial value of the viable cell concentration, $\mu_{\max }$ is 
the maximal specific growth rate $(\Delta \log (\mathrm{CFU} / \mathrm{g}) /$ day $), \lambda$ is the lag time (day) and $\mathrm{t}$ is the time (day), $\mathrm{N}_{\max }$ is the microbial threshold value (CFU/g), MAL is the time at which the microbiological threshold is reached (day) (i.e., the time at which $\mathrm{N}(\mathrm{t})$ is equal to $\mathrm{N}_{\max }$ ).

\subsection{Statistical Analysis}

Differences between the fitting parameters (MAL values) were compared using oneway variance analysis (ANOVA). A Duncan's multiple range test with the option of homogeneous groups $(p<0.05)$ was used to determine the significance between the means. STATISTICA 7.1 for Windows (Stat-Soft, Inc, Tulsa, OK, USA) was used for this purpose.

\section{Results}

In this study, the evolution of the microbial quality during the refrigerated storage of Giuncata cheese was assessed by monitoring the growth of both Pseudomonas spp. and total coliforms as representative spoilage microbial groups [3,15,31]. In addition, to evaluate the effects of the two different natural compounds on the cheese quality, the viable cell concentration of lactic acid bacteria was monitored. The results are reported in the following for each group. Figure 1 shows the evolution of Pseudomonas spp.'s viable cell concentration in the control cheese and some of the investigated samples (runs 1, 5, 7 and 11).

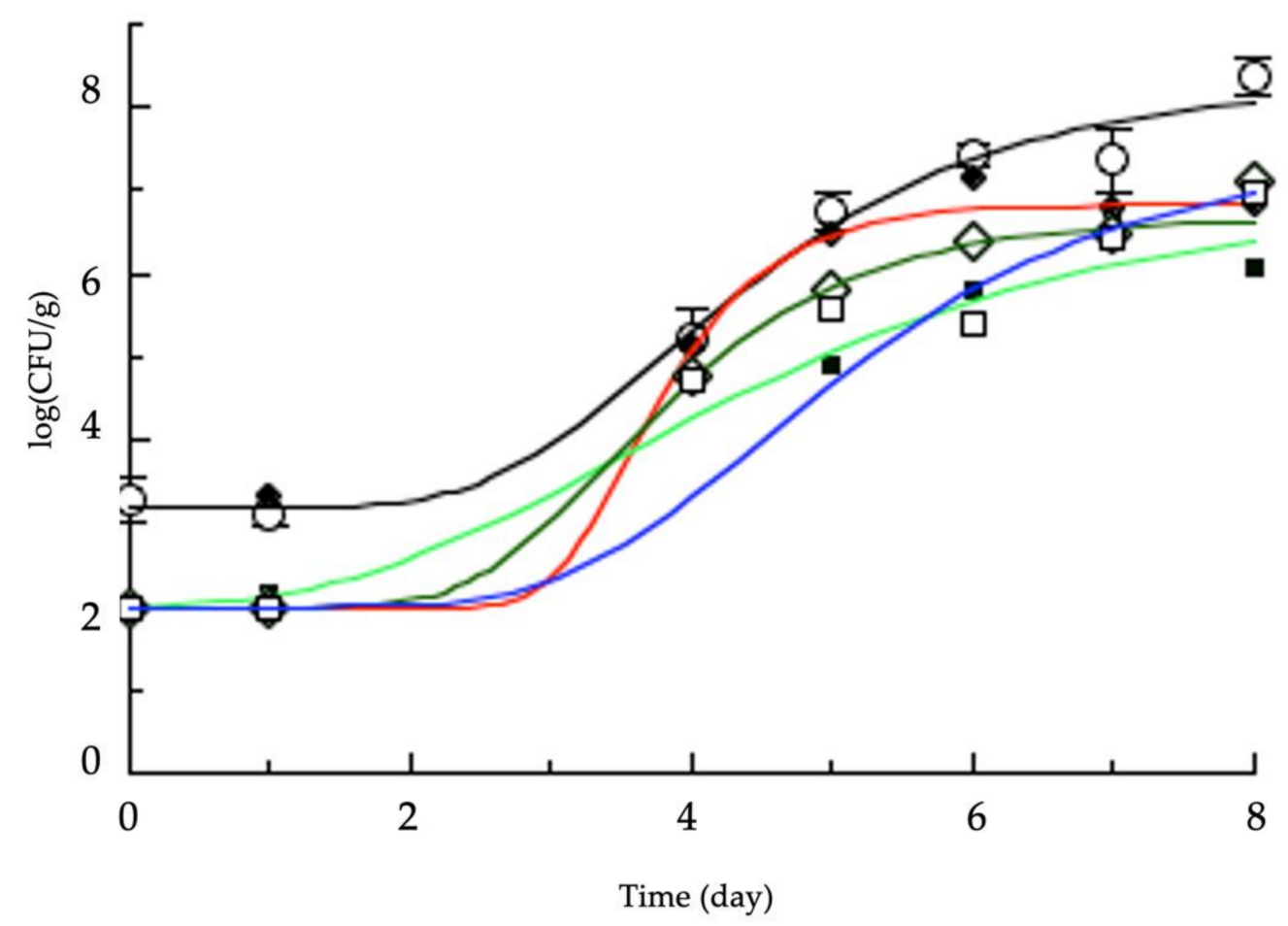

Figure 1. Best fit of modified Gompertz equation (Equation (1)) to the experimental data on the growth kinetics of Pseudomonas spp. Experimental data are presented as means \pm standard deviation. Control $(\bigcirc)$-Giuncata without any compounds; run $1(\diamond)$-Giuncata with 250 ppm lemon extract and 30 ppm chitosan; run 5 (ם) - Giuncata with 500 ppm lemon extract and without chitosan; run 7 $(\diamond)$-Giuncata with 60 ppm chitosan and without lemon extract; run 11 ( $\square$ )—Giuncata with 500 ppm lemon extract and 60 ppm chitosan.

Data related to the control cheese showed a short lag phase, followed by an increase in the viable cell concentration until the stationary phase was attained (about $8 \log (\mathrm{CFU} / \mathrm{g})$ ). A different trend was found when chitosan or lemon extract was used during the process. As can be inferred from the data shown in Figure 1, the presence of the antimicrobials slowed down the growth of Pseudomonas spp. compared with the control sample. In fact, a more pronounced lag phase and a reduced microbial concentration at the stationary 
phase were found in all the samples obtained with active agents (runs 1, 5, 7 and 11). Some further differences between these runs can be highlighted. Specifically, in run 1, the kinetic growth was more similar to the control and, therefore, Pseudomonas spp. proliferation reached the threshold within the first 4 days, which also happened for the control cheese. In contrast, a significant delay in microbial proliferation was recorded in runs 5, 7 and 11 . To quantitatively determine the effectiveness of the tested compounds regarding inhibiting the Pseudomonas spp. growth cycle, Equation (1) was fitted to the experimental data. The value of $\log \left(\mathrm{N}_{\max }\right)$ was set to 6 because at this level of contamination with Pseudomonas spp., alterations in the product begin to appear [4,5]. The fitting procedure allowed for determining the MAL values related to Pseudomonas $\left(\mathrm{MAL}^{\mathrm{P}}\right)$ for each combination of the two preservatives under study (Table 2).

Table 2. Microbial acceptability limit (MAL) values relative to Pseudomonas spp. (MAL ${ }^{\mathrm{P}}$ ) and coliforms $\left(\mathrm{MAL}^{\mathrm{C}}\right.$ ) of each investigated run. P-MAL is the lowest value between $\mathrm{MAL}^{\mathrm{P}}$ and $\mathrm{MAL}^{\mathrm{C}}$ and it is considered the MAL value of the entire product.

\begin{tabular}{cccc}
\hline Sample & $\begin{array}{c}\mathbf{M A L}^{\mathbf{P}} \\
\text { (Day) }^{\text {Da }}\end{array}$ & $\begin{array}{c}\mathbf{M A L}^{\mathbf{C}} \\
\text { (Day) }\end{array}$ & $\begin{array}{c}\text { P-MAL } \\
\text { (Day) }\end{array}$ \\
\hline CNT & $4.5 \pm 0.2^{\mathrm{a}}$ & $6.7 \pm 0.3^{\mathrm{ab}}$ & $4.5 \pm 0.2^{\mathrm{a}}$ \\
Run 1 & $4.5 \pm 0.4^{\mathrm{a}}$ & $5.7 \pm 1.8^{\mathrm{ab}}$ & $4.5 \pm 0.4^{\mathrm{a}}$ \\
Run 2 & $4.6 \pm 0.2^{\mathrm{a}}$ & $>8$ & $4.6 \pm 0.2^{\mathrm{a}}$ \\
Run 3 & $5.3 \pm 0.5^{\mathrm{b}}$ & $>8$ & $5.3 \pm 0.5^{\mathrm{bc}}$ \\
Run 4 & $5.6 \pm 0.2^{\mathrm{bc}}$ & $>8$ & $5.6^{\mathrm{b}} \pm 0.2^{\mathrm{b}}$ \\
Run 5 & $6.5 \pm 0.6^{\mathrm{d}}$ & $>8$ & $6.5^{\mathrm{a}} \pm 0.6^{\mathrm{d}}$ \\
Run 6 & $4.6 \pm 0.2^{\mathrm{a}}$ & $6.8 \pm 0.3^{\mathrm{b}}$ & $4.6 \pm 0.2^{\mathrm{a}}$ \\
Run 7 & $5.4 \pm 0.2^{\mathrm{b}}$ & $6.5 \pm 0.9^{\mathrm{ab}}$ & $5.4 \pm 0.2^{\mathrm{b}}$ \\
Run 8 & $5.4 \pm 0.1^{\mathrm{b}}$ & $6.4 \pm 0.5^{\mathrm{ab}}$ & $5.4 \pm 0.1^{\mathrm{b}}$ \\
Run 9 & $4.6 \pm 0.2^{\mathrm{a}}$ & $5.3 \pm 0.7^{\mathrm{ab}}$ & $4.6 \pm 0.2^{\mathrm{ac}}$ \\
Run 10 & $5.5 \pm 0.2^{\mathrm{b}}$ & $5.9 \pm 0.4^{\mathrm{ab}}$ & $5.5 \pm 0.2^{\mathrm{b}}$ \\
Run 11 & $6.1 \pm 0.4^{\mathrm{cd}}$ & $5.1 \pm 0.8^{\mathrm{a}}$ & $5.1 \pm 0.8^{\mathrm{abc}}$ \\
\hline
\end{tabular}

Data are presented as mean \pm standard deviation. ${ }^{\text {a-d }}$ Data in columns with different letters are significantly different $(p<0.05)$.

The data shown in the first column of Table 2 highlight that most combinations of chitosan and lemon extract improved the microbial stability because they promoted a significant delay of the Pseudomonas spp. proliferation. In fact, in most cases, a MAL ${ }^{\mathrm{P}}$ value higher than that of the control cheese was found, thus suggesting that chitosan alone, lemon extract alone or their proper combination contributed to controlling microbial proliferation. The antimicrobial effects of chitosan are well-known in the literature; however, it is also recognized that the antimicrobial activity of chitosan varies because this activity is associated with its physicochemical characteristics and depends on the type of microorganism [18]. Regarding lemon extract, data relating to dairy applications show that it may exert an inhibitory effect on the spoilage of mozzarella cheese [15,32]. Literature data recorded on different food matrices also confirmed the pronounced antimicrobial effect of citrus essential oils $[33,34]$. The significant increases in the $\mathrm{MAL}^{\mathrm{P}}$ values for runs 5 and 11, compared with the sample without any active agent (CNT), suggest that synergies between the tested natural compounds occurred and that they could be advantageously used in the Giuncata cheese production process.

Figure 2 shows the evolution of the total coliform count over the 8 days of storage in some of the investigated runs (runs 1, 5, 7 and 11). As can be inferred from the data shown in Figure 2, the control had a short lag phase, followed by a steady increase in the viable cell concentration up to the stationary phase (about $6 \log (\mathrm{CFU} / \mathrm{g})$ ). For the active samples, different results were found depending on the run being considered. Specifically, while run 5 was the best one, runs 1 and 11 did not work very well. Run 7 was more similar to the control. To quantitatively compare these experimental findings, the MAL values that were related to coliforms $\left(\mathrm{MAL}^{\mathrm{C}}\right.$ ) were determined according to the same procedure reported 
above for Pseudomonas spp. The results are also listed in the second column of Table 2. As stated in DPR 54/97 [35], the value of $\log \left(\mathrm{N}_{\max }\right)$ was set to 5 . As can be seen, some runs presented a $\mathrm{MAL}^{\mathrm{C}}$ that was similar to the control, whereas four runs did not reach the coliforms threshold, thus suggesting that for these samples, the $\mathrm{MAL}^{\mathrm{C}}$ was higher than 8 days. To sum up, as happened with Pseudomonas spp., in most cases, the combinations of the two natural compounds extended the coliform microbial acceptability limit. These results agree with the literature data relating to synergies between natural compounds and their interactions with food components in controlling microbial growth [25].

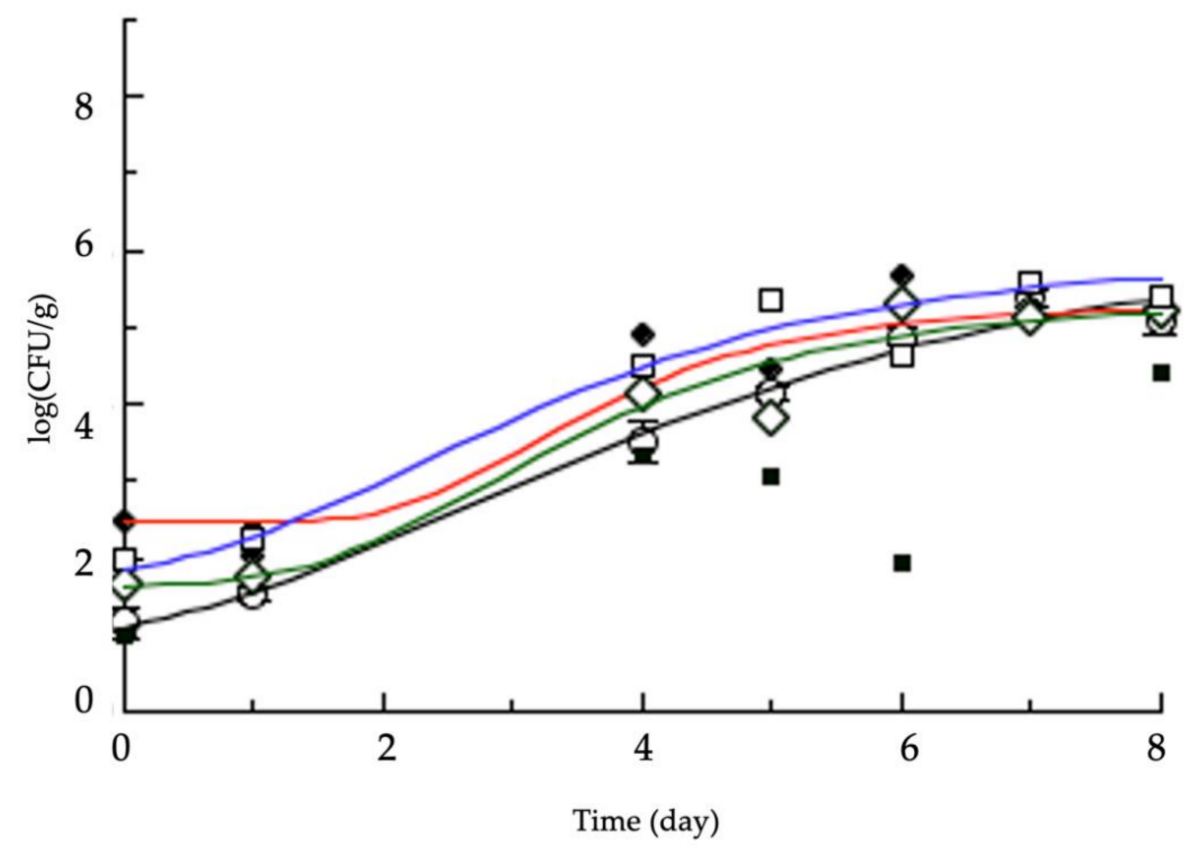

Figure 2. Best fit of the modified Gompertz equation (Equation (1)) to the experimental data on the growth kinetics of total coliforms. Experimental data are presented as means \pm standard deviation. Control $(\bigcirc)$ - Giuncata without any compounds; run $1(\checkmark)$-Giuncata with 250 ppm lemon extract and 30 ppm chitosan; run 5 (ם) - Giuncata with 500 ppm lemon extract and without chitosan; run 7 $(\diamond)$-Giuncata with 60 ppm chitosan and without lemon extract; run 11 ( $\square$ )—Giuncata with 500 ppm lemon extract and 60 ppm chitosan.

Figure 3 shows the growth kinetics of lactic acid bacteria in some of the investigated runs during the entire observation period (runs 1, 5, 7 and 11). Similar results were also obtained for all the other runs. As can be inferred from Figure 3, the functional microorganisms grew during the refrigerated storage. Moreover, there were no marked differences between the control sample and those containing the active compounds, thus demonstrating that the natural agents did not affect the growth of lactic acid bacteria to a great extent. This experimental finding is in agreement with what is reported in the literature. In fact, among the generally sensitive Gram-positive bacteria, lactic acid bacteria are the most resistant to essential oils or chitosan $[14,36]$. The inefficiency of the tested antimicrobial compounds on useful dairy bacteria is particularly important for fresh cheese because it is increasingly advertised as being "preservative-free and rich in viable lactic acid bacteria".

The total microbial counts were similar in all the samples (data not shown). As one would expect, their viable cell concentration slightly increased over the storage period. 

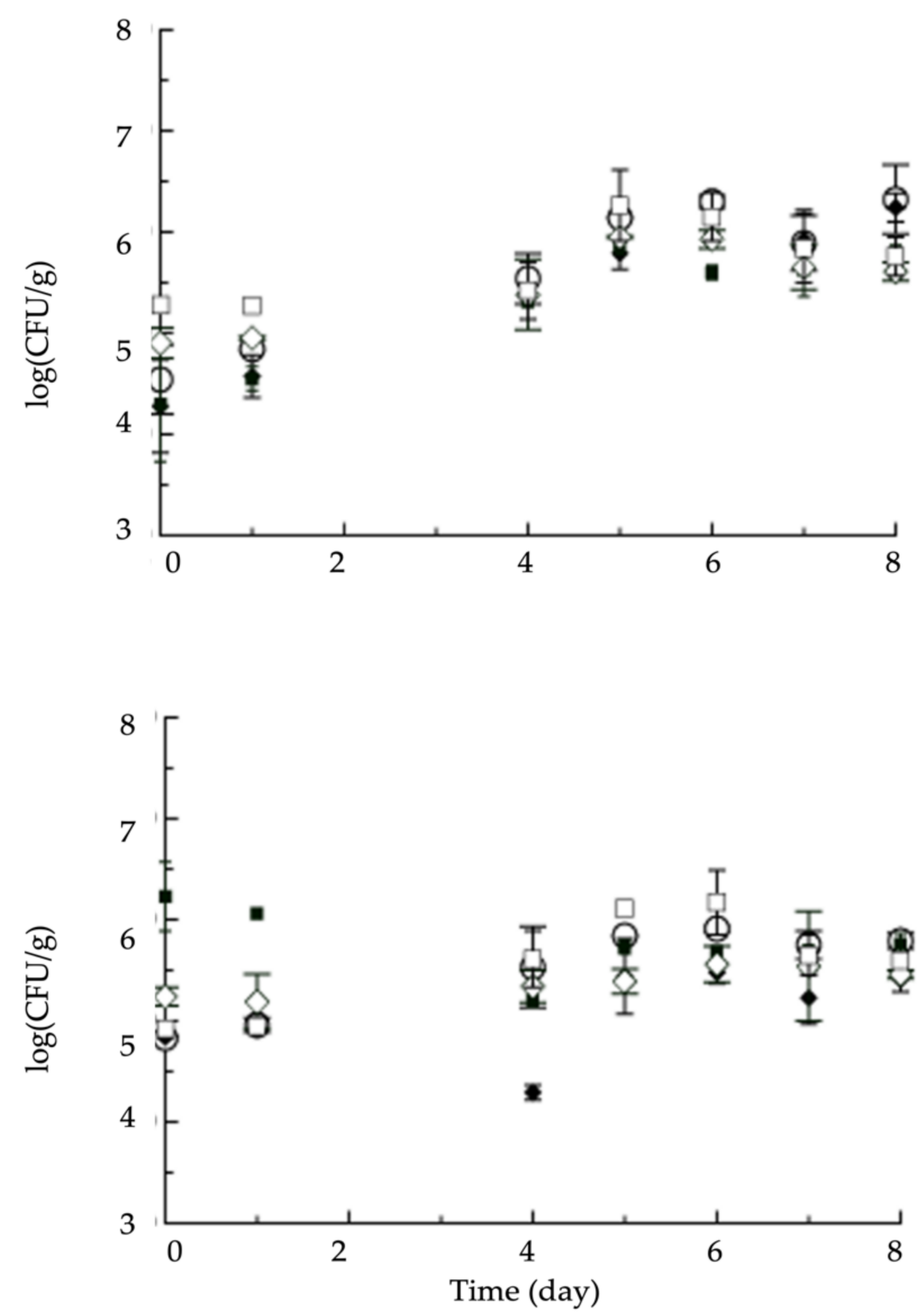

Figure 3. Evolution of lactic acid bacteria in Giuncata cheese during the storage period (8 days). Experimental data are presented as means \pm standard deviation. Control $(\bigcirc)$-Giuncata without any compounds; run $1(\diamond)$-Giuncata with 250 ppm lemon extract and 30 ppm chitosan; run $5(\mathbf{\square})$ - Giuncata with 500 ppm lemon extract and without chitosan; run $7(\diamond)$ —Giuncata with 60 ppm chitosan and without lemon extract; run $11(\square)$ - Giuncata with 500 ppm lemon extract and 60 ppm chitosan.

Results regarding the $\mathrm{pH}$ (Figure 4) also show similar trends, with casual fluctuations within a small range. The most striking result of Figure 4 is the lack of statistically significant differences between the samples in each run throughout the entire observation period. In fact, the $\mathrm{pH}$ data were all superimposed for different control and active samples. This experimental evidence of $\mathrm{pH}$ values not being affected by the two active compounds suggests that the observed antimicrobial activity could be exclusively ascribed to the efficacy of the investigated natural compounds [15]. Regarding the $\mathrm{pH}$ decrease over time, a possible explanation could be ascribed to the production process without a starter culture, as reported in the literature for other fresh cheese [37] 


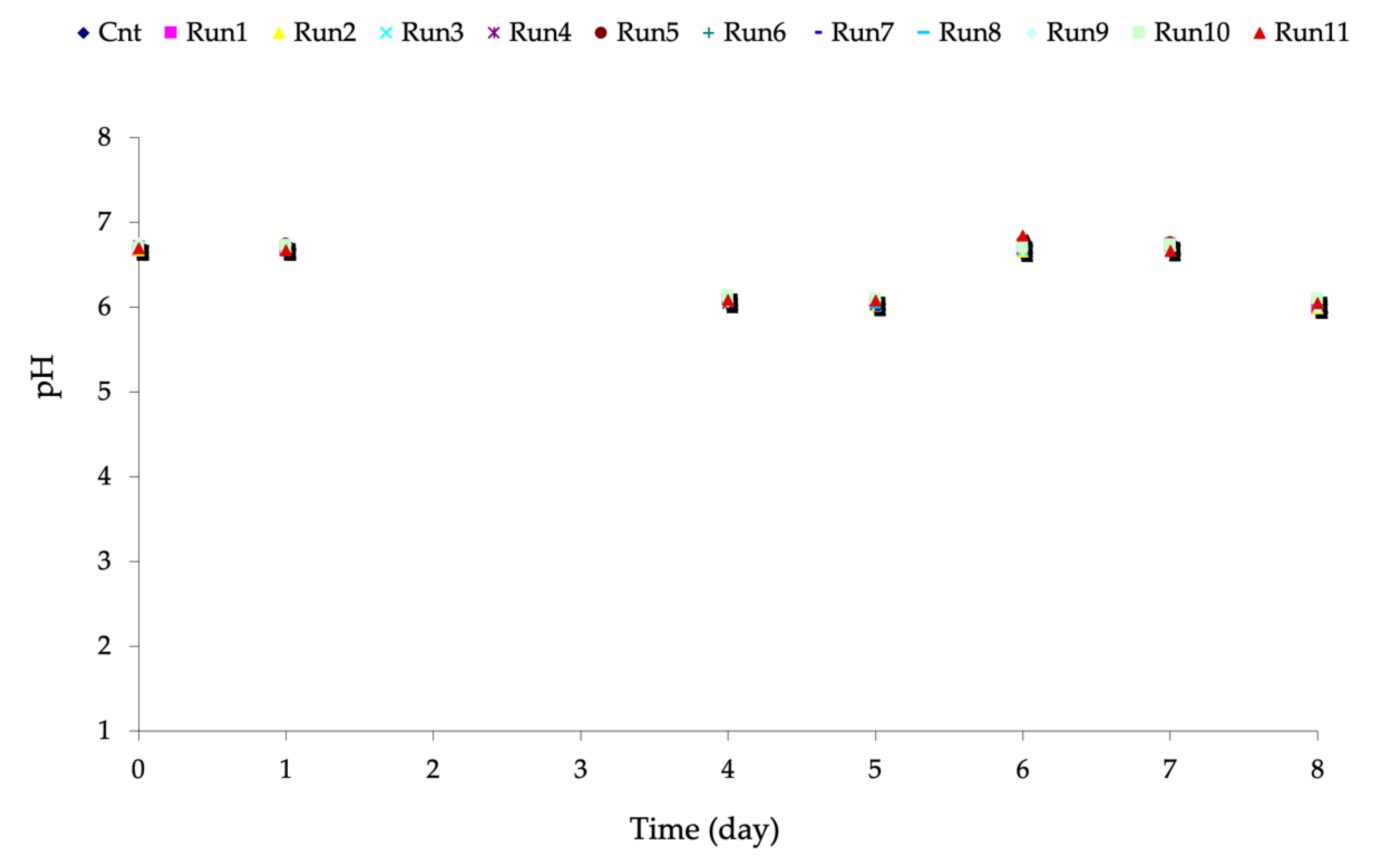

Figure 4. Evolution of $\mathrm{pH}$ in Giuncata cheese samples during the storage period (8 days).

Unfortunately, a comparison between the two selected preservatives with published data is very difficult, as the outcomes of related tests are affected by numerous factors, such as the food matrix and, of course, the sources of the antimicrobial compounds [18]. The composition of essential oils can greatly depend upon the geographical region, the variety, the age of the plant, the method of drying and the extraction method [38]. In addition, some intrinsic food properties (fat/protein/water content, antioxidants, preservatives, $\mathrm{pH}$ and salt) and extrinsic determinants (temperature, packaging and target microorganisms) can also influence the antimicrobial effect of these compounds [9]. It is also reported that during the application of an antimicrobial compound to food, interactions between phenolic compounds and some food components can occur [26,27].

In order to evaluate the synergic effect of the selected natural compounds on the microbial stability of Giuncata, the CCD approach was put to use. Towards this aim, the product microbial acceptability limit (hereinafter referred to as P-MAL) was taken into account. The P-MAL was defined as the lowest value between the MAL ${ }^{\mathrm{P}}$ and the $\mathrm{MAL}^{\mathrm{C}}$. The values of P-MAL are listed in the last column of Table 2 for each run. As can be inferred, the P-MAL values of most samples were significantly different from that of the control cheese, except for runs 1, 2 and 6 . Finally, run 5 recorded the best P-MAL value. The approach used to consider the lowest value between $\mathrm{MAL}^{\mathrm{P}}$ and the $\mathrm{MAL}^{\mathrm{C}}$ gave us a global idea of the single and combined effects of selected antimicrobials. However, in order to determine the effects of linear, quadratic and interactive terms of the independent variables on the dependent one, the best fit of Equation (2) was used:

$\mathrm{P}-\mathrm{MAL}=0.010022$ [lemon extract] +0.076685 [chitosan] -0.000151 [lemon extract] [chitosan]

The R-value indicates the adequacy of the model proposed; it was equal to 0.9832 . The F-value represents the level of significance; it was equal to $77.369(p<0.0001)$, while the standard error was equal to 1.11 .

A three-dimensional surface plot can be advantageously used to assess the influence of the independent variables on P-MAL values. In particular, a 3D graph was obtained by plotting the P-MAL values as a function of the two investigated independent variables. From the graph reported in Figure 5, it is worth noting that the two substances, when separately used, increased the antimicrobial effectiveness and, consequently, the P-MAL value. In fact, we can note that the colour shifted from green to red if each compound were used alone. In particular, the graph highlights that the maximum MAL value was present 
when the lemon and the chitosan were used individually at concentrations of $500 \mathrm{ppm}$ and $60 \mathrm{ppm}$, respectively, which represent the central levels of the experimental factors.

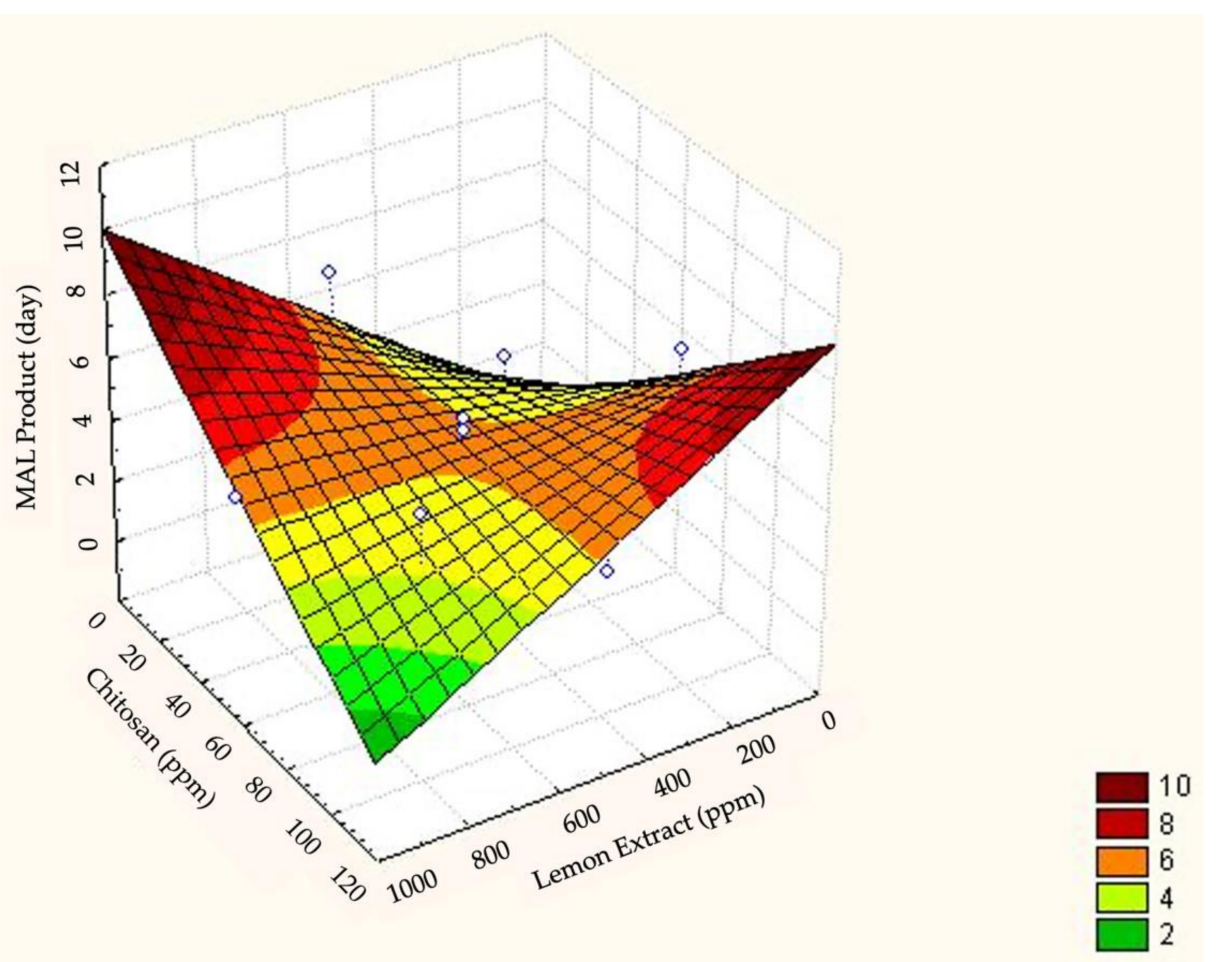

Figure 5. Effects of the interaction between lemon extract and chitosan on the microbial acceptability limit P-MAL (day) of Giuncata cheese.

This finding is in accordance with literature data related to compounds of natural origin, in particular, essential oils applied to food. In fact, data from other studies that assessed the combination of natural active compounds found that they may lead to additive, synergistic or antagonistic effects $[24,39]$. The data from the current study are particularly comparable with the results of Gammariello et al. [16], which were related to the use of chitosan and lemon extract during the production process of fiordilatte cheese. These authors also showed that the contact method of the active agents with microorganisms plays a key role in antimicrobial effectiveness. Therefore, the inclusion of chitosan and lemon extract directly into milk during processing generated interactions between them and with food components with high probability, which were responsible for the recorded antimicrobial efficacy. In addition, it is also worth noting that essential oils comprise a large number of components and, therefore, it is likely that their mode of action involves several targets in the bacterial cell.

\section{Conclusions}

Both chitosan and lemon extract were valid compounds regarding their effects on the microbial proliferation of Giuncata cheese without compromising the lactic acid bacteria. The final results from the CCD demonstrated that chitosan and lemon extract worked well when applied individually, in particular, when $500 \mathrm{ppm}$ of lemon extract or $60 \mathrm{ppm}$ of chitosan were incorporated in the cheese formulation during its processing. The current research represents the first attempt to explore the potential of natural agents in typical fresh cheese produced without adding a starter culture and is therefore characterized by certain variability in microbial quality. This result could gain great attention from the dairy industrial sector since the strategy proposed in the current study was simple and cheap to be applied. It could prolong the shelf life of a perishable product that is only known and 
commercialized for a local market, thus promoting its diffusion beyond the local borders, allowing for added incomes for the producing areas.

Author Contributions: Conceptualization, M.A.D.N. and A.C.; methodology, M.A.D.N. and A.C.; formal analysis, D.G. and M.A.; data curation, M.A.D.N. and A.C.; writing-original draft preparation, D.G.; writing-review and editing, M.A.D.N. and A.C.; supervision M.A.D.N. and A.C. All authors have read and agreed to the published version of the manuscript.

Funding: This research received no external funding.

Institutional Review Board Statement: Not applicable.

Informed Consent Statement: Not applicable.

Data Availability Statement: The raw data will be made available upon request.

Conflicts of Interest: The authors declare no conflict of interest.

\section{References}

1. Fusco, V.; Quero, G.M.; Poltronieri, P.; Morea, M.; Baruzzi, F. Autochthonous and probiotic lactic acid bacteria employed for production of "advanced traditional cheeses". Foods 2019, 8, 412. [CrossRef]

2. Fikar, C.; Hirsch, P.; Gronalt, M. A decision support system to investigate dynamic last-mile distribution facilitating cargo-bikes. Int. J. Log. Res. Appl. 2018, 21, 300-317. [CrossRef]

3. Del Nobile, M.A.; Gammariello, D.; Conte, A.; Attanasio, M. A combination of chitosan, coating and modified atmosphere packaging for prolonging Fior di latte cheese shelf life. Carbohydr. Polym. 2009, 78, 151-156. [CrossRef]

4. Lacivita, V.; Mentana, A.; Centonze, D.; Chiaravalle, E.; Zambrini, V.A.; Conte, A.; Del Nobile, M.A. Study of X-ray irradiation applied to fresh dairy cheese. LWT Food Sci. Technol. 2019, 103, 186-191. [CrossRef]

5. Ricciardi, F.E.; Plazzotta, S.; Conte, A.; Manzocco, L. Effect of pulsed light on microbial inactivation, sensory properties and protein structure of fresh ricotta cheese. LWT Food Sci. Technol. 2021, 139, 110556. [CrossRef]

6. Papaioannou, G.; Chouliara, I.; Karatapanis, A.E.; Kontominas, M.G.; Savvaidis, I.N. Shelf-life of a Greek whey cheese under modified atmosphere packaging. Int. Dairy J. 2007, 17, 358-364. [CrossRef]

7. Gammariello, D.; Conte, A.; Attanasio, M.; Del Nobile, M.A. Effect of modified atmospheres on microbiological and sensorial properties of Apulian fresh cheeses. Afr. J. Microbiol. Res. 2009, 3, 370-378.

8. Amiri, A.; Ramezanian, A.; Mortazavi, S.M.H.; Hosseini, S.M.H.; Yahia, E. Shelf-life extension of pomegranate arils using chitosan nanoparticles loaded with Satureja hortensis essential oil. J. Sci. Food Agric. 2021, 101, 3778-3786. [CrossRef]

9. Ahmed, L.I.; Ibrahim, N.; Abdel-Salam, A.B.; Fahim, K.M. Potential application of ginger, clove and thyme essential oils to improve soft cheese microbial safety and sensory characteristics. Food Biosci. 2021, 42, 101177. [CrossRef]

10. Hussain, M.A.; Sumon, T.A.; Mazumder, S.K.; Ali, M.M.; Jang, W.J.; Abualreesh, M.H.; Sharifuzzaman, S.M.; Brown, C.L.; Lee, H.T.; Lee, E.-W.; et al. Essential oils and chitosan as alternatives to chemical preservatives for fish and fisheries products: A review. Food Control 2021, 129, 108244. [CrossRef]

11. Casadidio, C.; Peregrina, D.V.; Gigliobianco, M.R.; Deng, S.; Censi, R.; Di Martino, P. Chitin and chitosans: Characteristics, eco-friendly processes, and applications in cosmetic science. Open Access Mar. Drugs. 2019, 17, 369. [CrossRef]

12. Yamada, K.; Akiba, Y.; Shibuya, T.; Kashiwada, A.; Matsuda, K.; Hirata, M. Water purification trough bioconversion of phenol compounds by tyrosinase and chemical adsorption by chitosan beads. Biotechnol. Prog. 2005, 21, 823-829. [CrossRef] [PubMed]

13. Irastorza, A.; Zarandona, I.; Andonegi, M.; Guerrero, P.; de la Caba, K. The versatility of collagen and chitosan: From food to biomedical applications. Food Hydroc. 2021, 116, 106633. [CrossRef]

14. Altieri, C.; Scrocco, C.; Sinigaglia, M.; Del Nobile, M.A. Use of chitosan to prolong mozzarella cheese shelf life. J. Dairy Sci. 2005, 88, 2683-2688. [CrossRef]

15. Gammariello, D.; Di Giulio, S.; Conte, A.; Del Nobile, M.A. Effects of natural compounds on microbial safety and sensory quality of Fior di Latte cheese, a typical Italian cheese. J. Dairy Sci. 2008, 91, 4138-4146. [CrossRef]

16. Gammariello, D.; Conte, A.; Del Nobile, M.A. Assessment of chitosan and extracts of lemon and sage as natural antimicrobial agents during Fior di latte cheesemaking. Int. J. Dairy Technol. 2010, 63, 530-537. [CrossRef]

17. Zheng, L.Y.; Zhu, J.F. Study on antimicrobial activity of chitosan whit different molecular weight. Carboh. Polym. 2003, 54, 527-530. [CrossRef]

18. Ke, C.L.; Deng, F.S.; Chuang, C.Y.; Lin, C.H. Antimicrobial actions and applications of Chitosan. Open Access Polym. 2021, 13, 904.

19. De Medeiros Barbosa, I.; da Costa Medeiros, J.A.; de Oliveira, K.T.R.; Gomes-Neto, N.J; Tavares, J.F.; Magnani, M.; de Souza, E.L. Efficacy of the combined application of oregano and rosemary essential oils for the control of Escherichia coli, Listeria monocytogenes and Salmonella Enteritidis in leafy vegetables. Food Control 2016, 59, 468-477. [CrossRef]

20. Boskovic, M.; Djordjevic, J.; Ivanovic, J.; Janjic, J.; Zdravkovic, N.; Glisic, M.; Glamoclija, N.; Branislav, B.; Vesna, D.; Baltic, M. Inhibition of Salmonella by thyme essential oil and its effect on microbiological and sensory properties of minced pork meat packaged under vacuum and modified atmosphere. Int. J. Food Microbiol. 2017, 258, 58-67. [CrossRef] 
21. Araújo, M.K.; Gumiela, A.M.; Bordin, K.; Luciano, F.B.; Macedo, R.E.F.D. Combination of garlic essential oil, allyl isothiocyanate, and nisin $\mathrm{Z}$ as bio-preservatives in fresh sausage. Meat Sci. 2018, 143, 177-183. [CrossRef] [PubMed]

22. Targino de Souza Pedrosa, G.; Pimentel, T.C.; Gavahian, M.; Lucena de Medeiros, L.; Pagan, R.; Magnani, M. The combined effect of essential oils and emerging technologies on food safety and quality. LWT Food Sci. Technol. 2021, 147, 111593. [CrossRef]

23. Kavas, G.; Kavas, N. Use of egg white protein powder-based films fortified with sage and lemon balm essential oils in the storage of lor cheese. Mljekarstvo Časopis Za Unaprjeđenje Proizv. Prerade Mlijeka 2016, 66, 99-111.

24. Delaquis, P.; Stanich, J.K.; Girad, B.; Mazza, G. Antimicrobial activity of individual and mixed fraction of dill, cilantro, coriander and eucalyptus essential oils. Int. J. Food Microbiol. 2002, 74, 101-109. [CrossRef]

25. Hyldgaard, M.; Mygind, T.; Meyer, R.L. Essential oils in food preservation: Mode of action, synergies, and interactions with food matrix components. Front. Microbiol. 2012, 3, 12. [CrossRef] [PubMed]

26. Ju, J.; Xie, Y.; Guo, Y.; Cheng, Y.; Qian, H.; Yao, W. The inhibitory effect of plant essential oils on foodborne pathogenic bacteria in food. Crit. Rev. Food Sci. Nutr. 2019, 59, 3281-3292. [CrossRef]

27. Corrêa, J.A.F.; dos Santos, J.V.G.; Evangelista, A.G.; Pinto, A.C.S.M.; de Macedo, R.E.F.; Luciano, F.B. Combined application of phenolic acids and essential oil components against Salmonella Enteritidis and Listeria monocytogenes in vitro and in ready-to-eat cooked ham. LWT Food Sci. Technol. 2021, 149, 111881. [CrossRef]

28. Gill, A.; Delaquis, P.; Russo, P.; Holley, R. Evaluation of antilisterial action of cilantro oil on vacuum packed ham. Int. J. Food Microbiol. 2002, 73, 83-92. [CrossRef]

29. Ghabraie, M.; Vu, K.D.; Tata, L.; Salmieri, S.; Lacroix, M. Antimicrobial effect of essential oils in combinations against five bacteria and their effect on sensorial quality of ground meat. LWT Food Sci. Technol. 2016, 66, 332-339. [CrossRef]

30. Gammariello, D.; Conte, A.; Attanasio, M.; Del Nobile, M. A study on the synergy of modified atmosphere packaging and chitosan on stracciatella shelf life. J. Food Process. Eng. 2009, 34, 1394-1407. [CrossRef]

31. Conte, A.; Gammariello, D.; Di Giulio, S.; Attanasio, M.; Del Nobile, M. Active coating and modified-atmosphere packaging to extend the shelf life of Fior di Latte cheese. J. Dairy Sci. 2009, 92, 887-894. [CrossRef] [PubMed]

32. Conte, A.; Scrocco, C.; Sinigaglia, M.; Del Nobile, M. Innovative Active Packaging Systems to Prolong the Shelf Life of Mozzarella Cheese. J. Dairy Sci. 2007, 90, 2126-2131. [CrossRef] [PubMed]

33. Conte, A.; Sinigaglia, M.; Del Nobile, M.A. Use of Lemon Extract To Inhibit the Growth of Malolactic Bacteria. J. Food Prot. 2007, 70, 114-118. [CrossRef] [PubMed]

34. Sengun, I.Y.; Karapinar, M. Effectiveness of household natural sanitizers in the elimination of Salmonella typhimurium on racket (Eruca sativa Miller) and spring onion (Allium cepa L.). Int. J. Food Microbiol. 2005, 98, 319-323. [CrossRef]

35. European Union (1997) DPR n. 54/97. Regolamento recante attuazione delle Dir. 92/46 e 92/47/CEE in materia di produzione e immissione sul mercato di latte e di prodotti a base di latte. Available online: http://www.quagest.com/download/DPR\%2054-9 7\%20latte.pdf (accessed on 11 August 2021).

36. Ouattara, B.R.; Simard, E.; Piette, G.; Begin, A.; Holley, R.A. Inhibition of surface spoilage bacteria in processed meats by application of antimicrobial films prepared whit chitosan. Int. J. Food Microbiol. 2000, 62, 139-148. [CrossRef]

37. Ramos, M.; Martín-Hernández, C.; Martín-Alvarez, P.; Juárez, M. Effects of freezing and frozen storage on the physicochemical and sensory characteristics of four types of goat's cheese. Eur. Food Res. Technol. 1990, 190, 325-330. [CrossRef]

38. Jerkovic, I.; Mastelic, J.; Milos, M. The impact of both the season of collection and drying on the volatile constituents of Origanum vulgare L. ssp. hirtum grown wild in Croatia. Int. J. Food Sci. Technol. 2001, 36, 649-654. [CrossRef]

39. Fu, Y.; Zu, Y.; Chen, L.; Shi, X.; Wang, Z.; Sun, S.; Efferth, T. Antimicrobial activity of clove and rosemary essential oils alone and in combination. Phytother. Res. 2007, 21, 989-994. [CrossRef] [PubMed] 